\title{
Assessment of Indonesian Higher Education Students' Critical Thinking Based on Merrill's First Principles of Instruction
}

\begin{abstract}
E. M. Rahayu ${ }^{1^{*}}$, W. Bandjarjani ${ }^{2}$
1,2 English Language Education Department, Universitas PGRI Adi Buana, Surabaya, Indonesia

*e-mail: endangmrahayu63@gmail.com¹wahyu.banjaryani.unipa@gmail.com²

Abstract

Studies in Indonesian Higher Education students'critical thinking skills, have shown that they still need reinforcement. Hereby, Merrill's First Principles of Instruction offers steps of activities to facilitate this. This article reports the results of a case study on the assessment of Indonesian Higher Education students'critical thinking skills in each step of Merrill's First Principles of Instruction (Problem, Actication, Demonstration, Application, and Integration) during Classroom Action Research Course for students of batch 2017 of English Language Education Department. Through descriptive qualitative analysis of assessment rubric of critical thinking, it was found that the assessments given in each step of Merrill's First Principles of Instruction could trigger the students' critical thinking skills assisting them to manage to formulate proposal for conducting Classroom Action Research. This provides insights to craft assessment in line with Merrill's First Principles of Instruction as to promote students' critical thinking skills. Therefore, it could be suggested for other researchers to conduct similar research using more careful and detailed criteria of critical thinking rubric when implementing Merrill's First Principles of Instruction.
\end{abstract}

Keywords: Critical Thinking Skills, Merrill's First Principles of Instruction

\section{Introduction}

The 21st Century learning brings its own set of changes and challenges that require teachers to be prepared, trained and equipped with the right skills that will help them meet the challenges in their profession. The effects of globalization and other pressures and challenges such as rapid technological advances, changing working patterns and the use of information have brought certain demands on education (Kayange \& Msiska, 2016; Nurtanto et al., 2020) in such a way that the cultivation of the 21 st century skills has become a necessity. The 21st Century learning enables students to master content while producing and synthesizing information from various subjects and sources with an understanding of diverse cultures (Bedir, 2019; Sutarto \& Jaedun, 2018). This learning requires students who can take advantage of advances in cognitive science and technology that are strategically arranged according to the 21st century skills (Valtonen et al., 2020). These competencies include collaboration, digital literacy, critical thinking, and solving problems to help students thrive in today's world (Kayange \& Msiska, 2016; Tican \& Deniz, 2019).

Student competencies for a successful Classroom Action Researcher in the internet/ information age and productivity, require them to possess the 21st century skills such as Learning skills (the four C's) include critical thinking and problem-solving skills, creativity, communication and collaboration skills (Sadaf \& Gezer, 2020; Steele et al., 2019). These skills must be demonstrated in learning, namely through; Literacy Skills (IMT) which include Information Literacy, Media Literacy, Technology Literacy; as well as Life Skills (FLIPS) which includes Flexibility, Leadership, Initiative, Productivity, and Social Skills (Lase, 2019). These skills must be constructed in learning (Malik, 2018). Students need to be prepared to have four standard competencies, namely understanding the characteristics of students, educational learning strategies meaning choosing the right approach and learning model, teaching materials, and assessments for the benefit of learning and mastering scientific and/or expertise, namely applying information and communication technology in learning

\footnotetext{
${ }^{*}$ Corresponding author.
}

Received January 5, 2021; Accepted June 25, 2021; Available online December 25, 2021

This is an open access article under the CC BY-SA license. Copyright $(2021$ by Author. Published by Universitas Pendidikan Ganesha 
planning, implementing learning, evaluating and managing it and having attitudes and personality (Faizah et al., 2019).

Thus, students do not only have the competence to design learning but also to research according to the scope of education and learning. Research standards for prospective teacher students cover the depth and breadth of the field of education and teacher training and excellence in education and teacher training. Therefore, the scope of student research includes: education policy, science education, teacher science, and teacher education (Faizah et al., 2019). Translating the meaning of student research standards is that Higher Education Institutions for Education Personnel (LPTK) can add Classroom Action Research courses in the curriculum.

The Classroom Action Research course for students of 2017 English Language Education Study Program was held in the even semester of the 2019/2020 academic year. During the implementation of the learning process for these courses in conjunction with the COVID-19 pandemic disaster, the Minister of Education and Culture issued a Circular of the Minister of Education and Culture No.03 year 2020 about learning conditions and facilities (Windhiyana, 2020). The method used during the COVID-19 pandemic was the blended learning method. The blended learning method is one of the methods that is considered effective for improving the cognitive abilities of students (Damanik, 2020). Online learning is basically a model of learning activities Classroom Action Research using a remote (internet) network, with the help of intermediary tools such as gadgets, laptops. Through this online learning, it is enough to help the world of education in Indonesia during the Covid-19 pandemic situation. In online learning like this, one can take advantage of information technology such as WhatsApp, google classroom, zoom, telegram or other media (Alsalhi et al., 2019; Damanik, 2020; Joseph \& Sherine, 2019).

This study has an urgency to describe the critical thinking skills assessment on each Merrill's First Principles of Instruction. Therefore, an instrument for assessing critical thinking skills is needed. Critical skills assessment instruments were developed several years ago, in fact they can still be used (Shavelson et al., 2019). The use of critical thinking skills assessment instruments is adjusted to current needs, namely evaluation information including real information, creative thinking to identify alternatives to interpreting observations, learning problem solving skills, and finally communicating ideas effectively (Grant \& Smith, 2018; Seventika et al., 2018). The indicators of critical thinking skills consist of interpreting problems with sub indicators namely mapping information based on information to identifying the similarities; analyzing the problem solution with sub indicators, finding the relevance of facts to the solution, applying the solution, evaluating the solution with sub indicators, reviewing each solution, and concluding with the sub-indicator making the right conclusions (Seventika et al., 2018).

The instrument for assessing critical thinking skills is valid, so what needs to be considered is content validity, form validity, reliability and honesty, therefore an assessment rubric is needed so that the results are in accordance with the specified standards (Teng \& Zhang, 2016). Student assignments in Classroom Action Research during the learning process using Merrill's First Principles of Instructionn are made in the form of essays, because the Classroom Action Research course is a subject that requires critical and creative reasoning skills from students. The stages of student assignments have been adjusted to the indicators of critical thinking skills assessment. The task starts with students critically analyzing examples of video shows of the learning process to find problems that can be made into research titles. Then they can plan a frame of mind in Classroom Action Research which is often referred to as the Plan, Action, Prepare, and Reflection cycle. The final step for students to plan a research method to become a proposal. All assignments undertaken by students are assessed using a critical thinking assessment rubric in order to obtain reliable and honest results.

This article reports the results of a case study on the assessment of Indonesian Higher Education students'critical thinking skills in each step of Merrill's First Principles of Instruction (Problem, Actication, Demonstration, Application, and Integration) during 
Classroom Action Research Course for students of batch 2017 of English Language Education Department.

\section{Method}

This study used a qualitative descriptive research design. The researchers used a qualitative descriptive research design because the results of the study were able to fully describe the process of assessing students' critical thinking skills in learning using Merrill's First Principles of Instruction in the Classroom Action Research course (Mohajan, 2018). This research was expected to be able to describe the process of assessing students' critical thinking skills in learning Classroom Action Research courses that use Merrill's First Principles of Instruction.

Sources of data in the study were students of the 2017 of Universitas PGRI Adi Buana Surabaya in the English Language Education Study Program with a total of 50 students who were programming the Classroom Action Research course. The research time coincided with the COVID-19 Pandemic disaster, so the method of implementing and collecting data used the blended learning method, namely online and offline. The research instruments used were participatory observation sheets and documents in the form of student assignments. Participatory observation sheets were used, because the researchers and data sources were involved in daily activities in learning that used Merrill's First Principles of Instruction, so collaborators were needed to record all researcher activities and data sources. Documents are records of several past events. The document can be written, a description of a situation, or someone's work. Documents are used to complement the use of the observation and questionnaire methods (Mohajan, 2018). The documents in this research were proposal assignments done by students and were collected at the end of the semester.

There are two ways of analyzing data during data collection, namely data that is ongoing and data that appears during a certain period. Activities in data analysis are namely; data reduction, data display, and conclusion / verification (Mohajan, 2018). 1. Data reduction. The activity of reducing / sorting data is summarizing, selecting the main thing, and focusing on important things, removing unnecessary data. 2. Data display. Presentation of data is used to understand what has happened, to plan next work steps based on the data that has been obtained. 3. Conclusion / verification. The conclusion / verification results are new findings supported by valid and consistent evidence, so the conclusions are credible conclusions.

\section{Result and Discussion}

\section{Results}

The research was conducted by involving a collaborator to help observe the process of implementing Merrill's First Principles of Instruction in the Classroom Action Research course. This was intended in order to get objective results from the research. The collaborator in this study was the member of the research as well as the teaching team. However, because at the time when the study was going on there was the COVID-19 pandemic, the research was conducted online. The implementation of the teaching and research used Zoom, Edmodo, WhatsApp, YouTube, Google Meet, and Google Classroom applications, so collaborator could observe the application of Merrill's First Principles of Instruction in the Classroom Action Research course by viewing the recording of the Zoom, You Tube application, Google Meet checking the Edmodo, WhatsApp, and Google Classroom. Observation of the application of the Merrill First Principles of Instruction was Classroom Action Research classes for one semester with sixteen face-to-face times, so the observation process was Classroom Action Research classes done face-to-face in the teaching and learning process. The results of observations made by collaborator on Merrill's First Principles of Instruction were as follows. 


\section{Observation Result}

At the beginning of the Classroom Action Research class, the lecture was conducted offline, because the COVID-19 pandemic did not yet exist. The pretest could be done offline. The pretest material was regarding the previous knowledge about Classroom Aaction Research. The pretest was of a multiple type consisting of 25 questions. The results showed that of the 50 students only $45 \%$ scored between $60-80$. This meant that the majority of students still had little understanding of Classroom Action Research. Therefore, the researcher prepared students' insights about Classroom Action Research by applying Merrill's First Principles of Instruction which can encourage them to think critically and creatively towards Classroom Action Research. The second to the sixteenth meeting of the learning process was Classroom Action Research online due to the COVID-19 pandemic. Before the second meeting, materials on the basic concepts of Classroom Action Research was sent through Edmodo and Google Classroom, so that students could download the materials, then they could learn beforehand and thought critically about teaching and learning problems that occured in class.

The second and third meeting of the Problem and Activation principles at Merrill's First Principles of Instruction began to be applied. Learning was carried out using YouTube media and the Google Meet application. The goal was to use these two applications so that lecturer could convey the concept and the scope of Classroom Action Research. The method used was the lecturer and assignments while the media used was a video learning process situation. The student's assignment was to analyze the video to see problems in the learning process and then they connected what they had learned previously from the materials that had been sent through the Edmodo application and Google Classroom as well as lecturers' explanations delivered via YouTube media and the Google Meet application. Then they practiced critical thinking on how to manage problems until the problem was formulated. At that time they also activated their experience in solving question and answer session problems by chatting on YouTube boxes and WhatsApp.

The 3rd to 15th meetings were intended to provide opportunities for students to activate their understanding of the aspects of Classroom Action Research mentioned above in the form of a power point presentation through videos sent to Google Classroom and Edmodo. The way they did was to apply the 3rd principle of Merrill's First Principles of Instruction (Demonstration). The feedback given by the lecturer had something to do with the critical thinking skills displayed by students in the form of a Classroom Action Research cycle plan. Submission of feedback on assignment presentations was done through the Zoom application, then students followed up in the form of a draft of Classroom Action Research proposal which was then sent via the Google Classrom application and Email. In the 8th meeting students took the midterm exam. The purpose of the midterm exam was to evaluate students' understanding of the Classroom Action Research concept that was delivered at the previous meeting. The midterm exam was an essay, where students made a Classroom Aaction Research plan in the form of a Classroom Action Research matrix.

After the midterm exam, in the next four sessions, students critically delivered their presentations on how to make analysis and reflection as one of the steps in Classroom Action Research, namely Plan, Action, Observation, and Reflection. In the next activity, students compiled Classroom Action Research proposals and research reports. The activities carried out by students were the application of Application principle. At the 13th meeting, students were given the task to critically analyze examples of Classroom Action Research proposals and Classroom Action Research reports, then assignments were sent via Edmodo and Google Classroom applications. The student's experience of critically analyzing the assignment given by the lecturer was a step for students to apply the 2nd principle (Activation) in order to get an idea that will be outlined in the Classroom Action Research proposal.

At the 14th and 15th meetings, there were student consultation sessions with the lecturer to discuss Classroom Action Research proposal. Classroom Action Research proposal that was done by students who were then given feedback by the lecturers through the Zoom application. The 16th meeting was the final semester examination, in which 
students developed a draft of Classroom Action Research proposal into a Classroom Action Research proposal complete with the necessary instruments. Student assignments were the application of the 5th principle of Merrill's First Principles of Instruction (Integration). Then, the Classroom Action Research proposal assignment was sent via the Google Classroom application and email. The student's final project in the form of a Classroom Action Research proposal was assessed using a rubric for critical thinking skills which was carried out using Merrill's First Principles of Instruction.

\section{Document Results in the form of Assignments}

The documents in this were proposal assignments done by students and were collected at the end of the semester. Because the Classroom Action Research course was conducted during in the COVID-19 pandemic, the learning processes were carried out through online processes, the assessment was carried out online using the google classroom application and email. Analysis of the assignments performed by students on each of the Merrill's First Principles of Instruction used the ILO critical skills assessment rubric (OliverHoyo, 2019). The indicators that were assessed through this rubric were explaining the subject matter, using real evidence, analysis of assumptions, alternative views, stating statements, and conclusions, implications and consequences.

In this phase, students practiced critically how to manage problems until the problem formulation, which is the first principle of Merrill's First Principles of Instruction (Problem). At the same time, they also activated their experience in solving question and answer session problems by having discussions through the YouTube box. This activity was the application of the $2^{\text {nd }}$ principle of Merrill's First Principles of Instruction (Activation). The results obtained were $50 \%$ of students (first bar) could analyze the problem critically to be appointed as the title of the Classroom Action Research proposal clearly and supported by various references, $40 \%$ of the results of the critical analysis of student problems that were appointed as the title of the Classroom Action Research proposal (second bar) were less clear and lacking reference support, then $10 \%$ of students (third bar) could not analyze the problems critically which could be the title of the Classroom Action Research proposal, because they were less interested in reading it.

Opportunities for students to activate their critical understanding of Classroom Action Research aspects which were presented in the form of PPT (power point) through videos sent to Google Classroom and Edmodo. In this way they applied the $3^{\text {rd }}$ principle of Merrill's First Principles of Instruction (Demonstration). The feedback given by the lecturer had something to do with the critical thinking skills displayed by students in the form of a Classroom Action Research cycle plan. The results of students presenting assignments on the principle of Demonstration obtained (first bar) was that $55 \%$ were able to answer questions posed by the lecturer clearly by describing the advantages and disadvantages of the task they were doing, $35 \%$ of students' answers when describing the advantages and disadvantages of the task (second bar) were less clear, and $10 \%$ of students (third bar) failed to answer questions when asked to explain the strengths and weaknesses of their assignment.

In the application principle, as many as $55 \%$ of students (first bar) could present about how to make analysis and reflection as one of the steps in Classroom Action Research, namely Plan, Action, Observation, Analysis and Reflection, how to prepare Classroom Action Research proposals and research reports, $35 \%$ of student presentation results (second bar) were less relevant, low authenticity of the assignments done; and $10 \%$ of the results of student presentations (third bar) were irrelevant between the proposal title and the planned Classroom Action Research cycle. The results of the feedback given by the assignment when they presented the assignment on the Demonstration Principle so that on the principle of Integration students could critically and creatively presented the Classroom Action Research Proposal. The result was $60 \%$ of students (first bar) could make conclusion, implementation and the consequences of the results of the analysis of problems found in the teaching and learning process to become Classroom Action Research proposals, 35\% of students (second bar) could make conclusion, implement and found the consequences which 
generally flowed from the analysis of problems found in the teaching and learning process to become Classroom Action Research proposals, and 5\% students (third bar) could conclude, implement and the found minimal consequences of analyzing the problems found in the teaching and learning process to become a Classroom Action Research proposal.

\section{Discussion}

Online learning that had never been done during the learning process made students receive offline the learning process, such as Classroom Action Research. Hence, when the pre-test was given related to the Classroom Action Research course, only 45\% understood the objectives of Classroom Action Research, while $55 \%$ of students had difficulty in understanding the Classroom Action Research course, because these courses were new for Class 2017 students and also they still did not have teaching experience yet, so they did not know what to improve in the learning process (Kennedy \& Lodge, 2018). In the learning process of the Classroom Action Research course there are also no learning principles that make it easier for students to understand about Classroom Action Research and that can also improve critical skills. Learning principles that are considered less important often lead to unexpected circumstances whose value becomes very meaningful, so these learning principles play a role in learning, especially in improving critical skills (Kennedy \& Lodge, 2018). Therefore, in this case a lecturer is required to choose the right learning principles so that the learning process can create learning experiences for students effectively and efficiently by providing the facilities needed to achieve learning goals and also improve critical skill (Changwong et al., 2018). Thus, lecturers must have the ability and creativity in selecting and applying learning principles by adjusting student characteristics to the situations and conditions they face, and improving critical thinking skills (Nadri \& Azhar, 2017).

The condition of distance learning still pays attention to the principles of learning which are expected to accommodate the 21 st century skills, namely by involving students' critical thinking skills. Merrill's First Principles of Instruction (MFPI) learning principles offer learning solutions for students to think critically and independently (Fang He, 2020). The learning principles are applied by Classroom Action Research lecturers with the hope of constructing competencies and helping students think critically to understand Classroom Action Research courses and helping students find problems that are part of the scope of Classroom Action Research (Lo et al., 2018). Research results (Jalilehvand, 2016) shows that students who learn using the First Principles of Instruction Merrill learning principle have higher creativity than students who use conventional learning principles (Badali et al., 2016; Ghasemi et al., 2016).

First Principles of instruction are Merrill's efforts recognizes what Reigeluth calls the basic method and Merril calls it the First Principles (Badali et al., 2016). Principle (as a basic method) is a relationship that is in a proper state regardless of a program or exercise. First Principles of Instruction are learning principles that pay attention to the benefits of each exercise given to students (Fang He, 2020). As the designer of the First Principles of Instruction, he considers that learning will be effective if each step is always equipped with applicable exercises. First Principles of Instruction states that learning is developed when students are involved in solving problems in the real world (Problems). There is activated knowledge as a basis for new knowledge (Activation), which is shown to students (Demonstration), students can apply new knowledge (Application), and they can integrate it into the world (Integration), Merrill (Fang He, 2020).

One of research that shows positive results about the strategy of delivering material in the learning process using Merrill principles is by Badali. The results of Badali, show that the learning model based on Merrill's First Principles of Instruction can improve student learning outcomes (Badali et al., 2016). Furthermore, another research results show that the application of MFPI can assist lecturers in applying these principles in teaching, or researchers and learning designers in assessing the quality of existing lectures (Lo et al., 2018). In addition, the MFPI can be applied to all learning and its use is positively correlated with the quality of teaching (Fang $\mathrm{He}, 2020$ ). 
Universal principles applicable to all reported teaching were positively correlated with teaching quality (Lo et al., 2018). According to Merrill, the First Principles of Instruction is a learning principle that is developed based on a combination of cognitive and constructivist theories. The principles are known as the First Principles of Instruction and are described as follows; first, learning increases when students are involved in solving real world problems (Problem). Second, learning increases when existing knowledge is activated as a basis for new knowledge (Activation). Thirdly, learning increases when new knowledge is shown to students (Demonstation). The fourth lesson increases when new knowledge is applied by students (Application). And lastly, learning increases when new knowledge is integrated into the world of students (Integration), Merril (Fang He, 2020).

The indicators of Merrill's First Principles of Instruction application in learning on each of the principles are as follows. The indicators in the first principle of the Problem are: assignments, the level of difficulty of the task, the development of problems from easy to complex ones. The indicator for the second principle of Activation is connecting past experiences with new experiences. Furthermore, the third principal indicators of the Demonstration are: consistency of the presentation using the guidelines provided for students by the lecturer and the accuracy of choosing the media during the presentation. The fourth principal indicator of Application is the consistency of the exercise with starting to reduce mentoring by the lecturer when implementing various kinds of problems. Lastly, the indicator of the last principle of Integration is: students can critically and creatively reflect, so they can find new ways to explore their new knowledge, (Yorganci, 2020).

Each of learning activities for Classroom Action Reseach courses that using Merrill's First Principles of Instruction needs to be assessed so that student learning outcomes are successful. As for the assessment of tasks in Classroom Action Research on each of the Merrill's First Principles of Instruction, a critical thinking skills assessment rubric is needed (Bhutta et al., 2019; Damayanti et al., 2017). Critical thinking skills are a thinking process to be able to apply, analyze, synthesize, and evaluate information generated from observing, reflecting, weighing or communicating (Fitriani et al., 2019). Thus, we need indicators of critical thinking skills assessment. Each function of critical thinking skills represents an important part of the quality of thinking and overall results such as: how to question problems, what the goals are, information is needed in the form of data, facts, observations, experiences or other sources that can help someone solve the problem at hand (Changwong et al., 2018; Grant \& Smith, 2018). Thus, someone can make interpretation and inference which serve to understand the data and draw conclusions, and implies a form of readiness to face the consequences of thinking processes. (Özelçi \& Çalışkan, 2019).

Based on the result of observation and documentation data, it could be explained that the students were already given chances to develop their critical thinking skills through the steps of MFPI, namely: Problem in which they were asked to solve real world problems in English Language Teaching; Activation in which they activated their existing knowledge as a basis of a knew knowledge; Demonstration where new knowledge was shown to students which them was applied by them in the Application Stage; Integration in which the new knowledge was integrated into the world, that was when they tried to formulate Classroom Action Research Proposal. These activities had been assessed using the rubric of critical thinking skills by ILO (Oliver-Hoyo, 2019) which measured the students ability to explain the subject matter using real evidence, to anlyze assumptions, to give alternative views, to state statements and conclusions, to propose implications and consequences. However, the results of assessment showed just good enough students critical thinking skills. This might have been due to the lack of detailed instructions in the assessment tasks.

\section{Conclusions and Suggestions}

Based on the data analysis on the observations of the teaching-learning process of Classroom Action Research course applying Merrill's First Principles of Instruction and also on the documents of students Classroom Action Research proposal as the final assessment of their performances in Classroom Action Research course, it could be concluded that the 
assessment model conducted during the lectures in Classroom Action Research course using Merrill's First Principles of Instruction as well as that given for the final semester assessment could trigger students'critical thinking skill although that was no optimal yet. This could be seen by the results in each step of Merrill's First Principles of Instruction. Therefore, it could be suggested for other researchers to conduct similar research using more careful and detailed criteria of critical thinking rubric when implementing Merrill's First Principles of Instruction.

\section{References}

Alsalhi, N. R., Eltahir, M. E., \& Al-Qatawneh, S. S. (2019). The effect of blended learning on the achievement of ninth grade students in science and their attitudes towards its use. Heliyon, 5(9). https://doi.org/10.1016/j.heliyon.2019.e02424.

Badali, M., Derakhshi, S. A., Bagheri, P., \& Ansari, M. R. (2016). The Effect of Team-Based Learning Coupled with Merrill's First Principles of Instruction on the Achievement of Learning Objectives in Nursing Students. Interdisciplinary Journal of Virtual Learning in Medical Sciences, 7(4). https://doi.org/10.5812/ijvlms.10812.

Bedir, H. (2019). Pre-service ELT teachers' beliefs and perceptions on 21st century learning and innovation skills (4Cs). Journal of Language and Linguistic Studies, 15(4), 231246. https://doi.org/10.17263/jlls.547718.

Bhutta, S. M., Chauhan, S., Ali, S. K., Gul, R., Cassum, S., \& Khamis, T. (2019). Developing a rubric to assess critical thinking in a multidisciplinary context in higher education. Scholarship of Teaching and Learning in the South, 3(1), 6. https://doi.org/10.36615/sotls.v3i1.69.

Changwong, K., Sukkamart, A., \& Sisan, B. (2018). Critical thinking skill development: Analysis of a new learning management model for Thai high schools. Journal of International Studies, 11(2), 37-48. https://doi.org/10.14254/2071-8330.2018/11-2/3.

Damanik, E. L. (2020). Blended Learning: An Innovative Approach on Social Sciences at Indonesian Higher Education. Education Quarterly Reviews, 3(1), 52-65. https://doi.org/10.31014/aior.1993.03.01.117.

Damayanti, R. S., Suyatna, A., Warsono, W., \& Rosidin, U. (2017). Development of Authentic Assessment instruments for Critical Thinking skills in Global Warming with a Scientific Approach. International Journal of Science and Applied Science: Conference Series, 2(1), 289. https://doi.org/10.20961/ijsascs.v2i1.16730.

Faizah, Z., Hanief, M., \& Dina, L. N. A. B. (2019). Profesionalisme Guru Dalam Meningkatkan Mutu Pendidikan di Madarsah Ibtidaiyah Tahfidz Al-Asyhar Malang. JPMI: Jurnal Pendidikan Madrasah Ibtidaiyah, 1(3), 134-140. http://riset.unisma.ac.id/index.php/JPMI/article/view/3234.

Fang He. (2020). Applying "First Principles of Instruction" as a Design Theory of the EFL Classroom: Findings from an Empirical Study. Computers and Education, 10(3), 243250. https://doi.org/10.1016/j.compedu.2017.12.003.

Fitriani, H., Asy'ari, M., Zubaidah, S., \& Mahanal, S. (2019). Exploring the prospective teachers' critical thinking and critical analysis skills. Jurnal Pendidikan IPA Indonesia, 8(3), 379-390. https://doi.org/10.15294/jpii.v8i3.19434.

Ghasemi, M., Mehraji, N., Kazem, B. S., \& Badali, M. (2016). The effect of integration of Merrill's first principles of instruction with team based learning on the achievement of recall and application of nursing students. Journal of Nursing Education, 5(1), 62-71. https://www.sid.ir/en/journal/ViewPaper.aspx?id=509900.

Grant, M., \& Smith, M. (2018). Quantifying Assessment Of Undergraduate Critical Thinking. Journal of College Teaching \& Learning (TLC), 15(1), 27-38. https://doi.org/10.19030/tlc.v15i1.10199.

Jalilehvand, M. (2016). Study the Impact of Merrill's First Principles of Instruction on Students' Creativity. Mediterranean Journal of Social Sciences, 7(2), 313-317. https://doi.org/10.5901/mjss.2016.v7n2p313.

Joseph, S., \& Sherine, A. (2019). Blended learning: An effective tool to teach presentation 
skills. International Journal of Engineering and Advanced Technology, 9(1), 962-969. https://doi.org/10.35940/ijeat.A9448.109119.

Kayange, J. J., \& Msiska, M. (2016). Teacher Education In China: Training Teachers For The 21st Century. The Online Journal of New Horizons in Education, 6(4), 204-210. https://www.tojned.net/journals/tojned/articles/v06i04/v06i04-24.pdf.

Kennedy, G., \& Lodge, J. M. (2018). Understanding difficulties and resulting confusion in learning: an integrative review. Frontiers in Education, 3, 318-328.

Lase, D. (2019). Education and Industrial Revolution 4.0. Jurnal Handayani, 10(1), 48-62.

Lo, C. K., Lie, C. W., \& Hew, K. F. (2018). Applying "First Principles of Instruction" as a design theory of the flipped classroom: Findings from a collective study of four secondary school subjects. Computers \& Education, 118, 150-165. https://doi.org/10.1016/j.compedu.2017.12.003.

Malik, R. S. (2018). Educational Challenges in 21St Century and Sustainable Development. Journal of Sustainable Development Education and Research, 2(1), 9-20. https://doi.org/10.17509/jsder.v2i1.12266.

Mohajan, H. K. (2018). Qualitative Research Methodology in Social Sciences and related Subjects. Journal of Economic Development, Environment and People, 7(1), 23-48. https://www.ceeol.com/search/article-detail ?id=640546.

Nadri, Y., \& Azhar, A. (2017). Self-Assessment of Critical Thinking Skills in EFL Writing Courses at the University Level: Reconsideration of the Critical Thinking Construct. Arab World English Journal, December 2016 ASELS Annual Conference Proceedings, December, 57-71. https://doi.org/10.2139/ssrn.2895540.

Nurtanto, M., Fawaid, M., \& Sofyan, H. (2020). Problem Based Learning (PBL) in Industry 4.0: Improving Learning Quality through Character-Based Literacy Learning and Life Career Skill (LL-LCS). Journal of Physics: Conference Series, 1573(1), 0-10. https://doi.org/10.1088/1742-6596/1573/1/012006.

Oliver-Hoyo, M. T. (2019). Designing a written assignment to promote the use of critical thinking skills in an introductory chemistry course. Journal of Chemical Education, 80(8), 899. https://doi.org/10.1021/ed080p899.

Özelçi, S. Y., \& Çalışkan, G. (2019). What is critical thinking? A longitudinal study with teacher candidates. International Journal of Evaluation and Research in Education, 8(3), 495-509. https://doi.org/10.11591/ijere.v8i3.20254.

Sadaf, A., \& Gezer, T. (2020). Exploring factors that influence teachers' intentions to integrate digital literacy using the decomposed theory of planned behavior. Journal of Digital Learning in Teacher Education. https://doi.org/10.1080/21532974.2020.1719244.

Seventika, S. Y., Sukestiyarno, Y. L., \& Mariani, S. (2018). Critical thinking analysis based on Facione (2015) - Angelo (1995) logical mathematics material of vocational high school (VHS). Journal of Physics: Conference Series, 983(1). https://doi.org/10.1088/1742-6596/983/1/012067.

Shavelson, R. J., Zlatkin-Troitschanskaia, O., Beck, K., Schmidt, S., \& Marino, J. P. (2019). Assessment of University Students' Critical Thinking: Next Generation Performance Assessment. International Journal of Testing, 19(4), 337-362. https://doi.org/10.1080/15305058.2018.1543309.

Steele, P., Johnston, E., Lawlor, A., Smith, C., \& Lamppa, S. (2019). Arts-Based Instructional and Curricular Strategies for Working With Virtual Educational Applications. Journal of Educational Technology Systems, 47(3), 411-432. https://doi.org/10.1177/0047239518803286.

Sutarto, H. P., \& Jaedun, M. P. D. (2018). Authentic assessment competence of building construction teachers in indonesian vocational schools. Journal of Technical Education and Training, 10(1), 91-108. https://doi.org/10.30880/jtet.2018.10.01.008.

Teng, L. S., \& Zhang, L. J. (2016). Effects of motivational regulation strategies on writing performance: A mediation model of self-regulated learning of writing in English as a second/foreign language. Metacognition and Learning, 13(2), 213-240. https://doi.org/10.1007/s11409-017-9171-4. 
Tican, C., \& Deniz, S. (2019). Pre-service teachers' opinions about the use of 21st century learner and 21st century teacher skills. European Journal of Educational Research, 8(1), 181-197. https://doi.org/10.12973/eu-jer.8.1.181.

Windhiyana, E. (2020). Dampak Covid-19 terhadap kegiatan pembelajaran online di sebuah perguruan tinggi kristen di Indonesia. Perspektif IImu Pendidikan, 34(1), 1-8. https://doi.org/10.21009/PIP.341.1.

Yorganci, S. (2020). Implementing flipped learning approach based on 'first principles of instruction' in mathematics courses. Journal of Computer Assisted Learning, 36(5), 763-779. https://doi.org/10.1111/jcal.12448. 